\title{
PLASMA FATTY ACIDS AFTER ADRENALIN INJECTION IN NOR- MAL SUBJECTS AND IN PATIENTS WITH LIVER DISEASE: PROGNOSTIC SIGNIFICANCE
}

\author{
By CHESTER M. JONES AND JOSEPHINE W. FISH \\ (From the Medical Clinic of the Massachusetts General Hospital and the Department of Medi- \\ cine, Harvard Medical School, Boston)
}

(Received for publication July 11, 1934)

During the past few years contradictory reports have appeared in the literature concerning the behavior of plasma fatty acids after the injection of adrenalin. Himwich and his collaborators $(1,2,3)$ claimed to have demonstrated a sharp rise in plasma fatty acids after the subcutaneous injection of adrenalin in dogs and after emotional stimulation. Koskoff and Dusser de Barenne (4) have reported similar findings after stimulation of the central end of the sciatic nerve. Rony and Ching (5), and Bornstein and Müller (6) on the contrary failed to find significant changes in plasma fatty acids after the injection of adrenalin in dogs. Actual decreases in the plasma fatty acids following the injection of adrenalin in dogs have been reported by Alpern and Collazza (7), Raab (8), and Alpern and Tutkewitsch (9). Finally Long and Venning (10) claim to have been unable to produce any change in plasma fatty acids after perfusion experiments with adrenalin on anesthetized cats and criticise the results obtained by Himwich and his coworkers as being due to faulty methods of determining fatty acids. According to Long and Venning the methods of Stewart and White (11) modified by Himwich, Friedman, and Spiers (12) are of no value for the estimation of fatty acids, owing to the fact that during saponification of alcohol-ether extracts of plasma, the glucose breaks down to organic acids which may be titrated as " fatty acids." A second source of error lies in the inclusion as "fatty acids" of the phosphoric acid liberated by hydrolysis of the phospholipids. Apparent increases in fatty acids, as determined by the above methods, were obtained by them after the addition of known amounts of glucose to samples of blood plasma. The above authors also noted that the addition of glucose to blood plasma produced no change in " fatty acids" when the latter were determined according to the method of Stoddard and Drury (13). In this method after saponification of the plasma extract the fatty acids are precipitated with an excess of $\mathrm{HCl}$, filtered off, thoroughly washed with a 5 per cent solution of $\mathrm{NaCl}$, dissolved in hot alcohol and titrated. By this method all organic acids except the fatty acids are removed before the final titration.

During a study of the blood lipids in cases of liver disease we have made use of the method of Stoddard and Drury ${ }^{1}$ and in order to reassure ourselves as to the accuracy of this method known amounts of glucose, lactic acid, cystine and phosphoric acid have been added to samples of whole blood, the fatty acid content of which had been determined previously by the above method. The results are in accord with those of Long and Venning. No changes were noted after the addition of these substances beyond the limits of error of the method and the results are given in Table I.

TABLE I

Results of the addition of known amounts of glucose, lactic acid, cystine and phosphoric acid to whole blood in the estimation of fatty acids by the method of Stoddard and Drury.

\begin{tabular}{|c|c|c|}
\hline \multirow{2}{*}{ Constituent added } & \multicolumn{2}{|c|}{ Blood fatty acid } \\
\hline & Original & $\begin{array}{c}\text { After } \\
\text { addition }\end{array}$ \\
\hline & $\begin{array}{l}\text { mgm. per } \\
100 \mathrm{cc} .\end{array}$ & $\begin{array}{c}\text { mgm. per } \\
100 \mathrm{cc} .\end{array}$ \\
\hline $\begin{array}{l}\text { Glucose, } 100 \text { mgm. per } 100 \text { cc. . . . . } \\
\text { Lactic acid, } 12 \mathrm{mgm} \text {. per } 100 \mathrm{cc} \ldots \ldots \\
\text { Cystine, } 50 \text { mgm. per } 100 \text { cc. } \ldots \ldots \\
\text { Phosphoric acid, } 17 \text { mgm. per } 100 \text { cc. }\end{array}$ & $\begin{array}{l}412 \\
256 \\
364 \\
368\end{array}$ & $\begin{array}{l}410 \\
252 \\
365 \\
368\end{array}$ \\
\hline
\end{tabular}

1 In our hands, in determinations on 100 consecutive specimens, duplicate checks have varied by not more than $\pm 5.0 \mathrm{mgm}$. This represents an error of not more than 2 per cent. We have used a saturated alcoholic solution ( 95 per cent) of thymol blue as an indicator instead of 0.3 per cent thymol blue in 50 per cent alcohol as described in Stoddard and Drury's article. 
OBSERVATIONS ON NORMAL SUBJECTS

Relying on the accuracy of the above method we determined to study in normal individuals the response of the plasma fatty acids to the intramuscular administration of adrenalin with the special purpose of combining such results with similar observations made on patients with disease of the liver. Such studies were suggested by the known high values for blood lipids in many cases with hepatic disturbances and were in progress before the publications of Himwich and his collaborators. It is of incidental interest that our results on normal individuals apparently confirm the qualitative findings made by these investigators although the quantitative changes are of much smaller magnitude. In normal subjects we have obtained what we believe to be significant increases in blood fatty acids after the injection of the adrenalin in every instance but one. The results are here reported and discussed.

\section{Experimental results}

The subjects were normal medical students or members of the hospital or laboratory staff. Control specimens of venous blood were taken about 14 hours after the last meal with the subject at rest, and $0.5 \mathrm{cc}$. of a 1 to 1000 solution of adrenalin (Parke, Davis and Co.) was then injected intramuscularly. Subsequent samples of venous blood were taken at intervals of one-half hour, one hour, and two hours. The subject remained at rest during the entire period. Blood sugar estimations as well as fatty acid determinations were made, and gave the usual post-adrenalin rise and fall. The results of the fatty acid determinations are shown in Table II.

A graphic representation of the average curve of fatty acid values obtained in this group of normal individuals is given in Figure 1 . It will be noted that the maximum rise in fatty acids is reached in most instances at the end of half an hour after the injection of adrenalin, although in a few subjects the maximum rise seemed to come after one hour. The average increase above the fasting level was $30 \mathrm{mgm}$. per $100 \mathrm{cc}$., with a maximum rise of 69 . In all but one instance the rise exceeded $12 \mathrm{mgm}$. but in one subject there was no appreciable rise. It will be observed that the only suggestion of a drop below the fasting
TABLE II

Changes in blood fatty acid noted in normal individuals following the intramuscular injection of $0.5 \mathrm{cc}$. adrenalin (1:1000 solution).

\begin{tabular}{c|c|c|c|c}
\hline \hline Subject & Fasting & $1 / 2$ Hour & 1 Hour & 2 Hours \\
\cline { 2 - 4 } & $\begin{array}{c}\text { mgm. per } \\
100 \text { cc. }\end{array}$ & $\begin{array}{c}\text { mgm. per } \\
100 \text { cc. }\end{array}$ & $\begin{array}{c}\text { mgm. per } \\
100 \text { cc. }\end{array}$ & $\begin{array}{c}\text { mgm. per } \\
100 \text { cc. }\end{array}$ \\
D. C...... & 270 & 286 & 320 & 270 \\
B. B...... & 294 & 298 & 298 & 271 \\
H. H..... & 259 & 280 & & 244 \\
C. M. J... & 296 & 320 & 277 & 285 \\
A. M..... & 257 & 295 & 241 & 270 \\
R. M...... & 330 & 348 & 330 & \\
M. R..... & 271 & 329 & 352 & 282 \\
G. T...... & 283 & 291 & 296 & 293 \\
J. W...... & 263 & 291 & 278 & 275 \\
T. U...... & 326 & 362 & 325 & 333 \\
T. Y...... & 302 & 363 & 285 & 266 \\
H. C...... & 319 & 388 & 343 & 336 \\
A. K...... & 419 & 437 & 488 & 424 \\
\end{tabular}

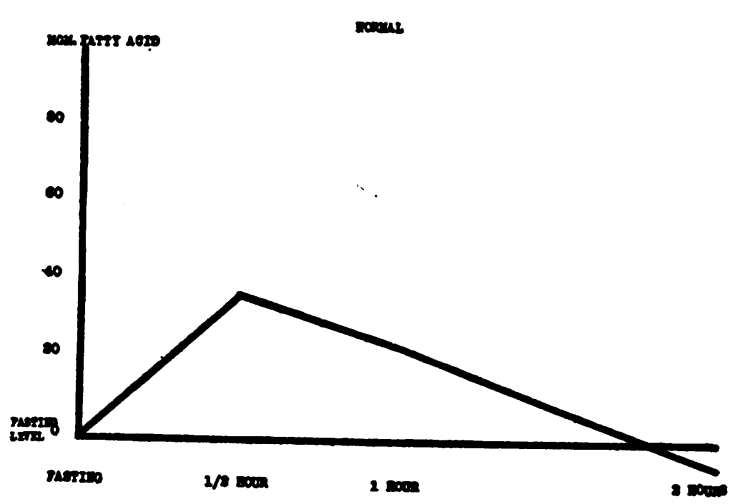

Fig. 1. Average Normal Curve Showing Rise from Fasting Level of Plasma fatty Acids after Injection of Adrenalin in a Group of Normal Individuals.

level was at the two hour determination. At the end of two hours the fatty acid values returned approximately to a fasting level in nearly every instance. The fasting level of the plasma fatty acids varied between 203 and $419 \mathrm{mgm}$. per $100 \mathrm{cc}$.

\section{Discussion}

As far as the accuracy of the above observations is concerned it would seem to us that there exists little reason for doubt. The findings were consistent in the normal individuals studied, and the rise in fatty acid coincided with the known rise in blood sugar resulting from the injection of adrenalin. The accuracy within narrow limits of error $( \pm 5.0 \mathrm{mgm}$.) of the Stoddard and Drury method for the determination of fatty acids has already been commented on and is attested by 
our own observations and by those of Long and Venning.

Granted that the methods used were accurate within the limits already noted ( $\pm 5.0 \mathrm{mgm}$.), we believe our findings constitute acceptable evidence that normally the fatty acid content of the blood rises appreciably and rather rapidly following the intramuscular injection of adrenalin in man. That the rise is within much narrower limits than those reported by Himwich and his collaborators may best be explained by the error inherent in the method used by them for the determination of fatty acids, and also by some difference in the amounts of adrenalin used. Our results, nevertheless, support their conclusions that adrenalin temporarily increases the blood lipids.

The discrepancy between our results and those reported by other investigators who found no rise or an actual fall in fat values after the injection of adrenalin is less easy to explain. It is not necessarily probable that the difference lies in the fact that most of their observations were on animals which might react in another manner than man. Many of the observations were made on anesthetized or decerebrate animals, however, and this may have altered an otherwise normal sympathetic response.

Furthermore, the observations of other investigators, in most instances, were made at much longer intervals than one-half hour and one hour after the injection of adrenalin, and for this reason an early rise might have been missed. In some instances the adrenalin was given by continuous intravenous administration over a period of hours and in one set of experiments it was administered subcutaneously. Such variations in the administration of the drug may well have altered the type of response obtained.

Another important consideration arises in relation to the fact that other investigators for the most part confined their studies to animals. Inasmuch as the phenomenon under discussion is essentially a sympathetic response, it should be expected that any emotional disturbance could produce similar blood changes in a very short time. Disturbance of the animal during the period of early anesthesia or during the handling of the animal might evoke a discharge of adrenalin with resulting change in blood values in a few minutes. In some observations on rabbits (14) we found it extremely difficult to avoid fictitious high resting values for blood sugar and fatty acids because of the apprehension the animals experienced during the withdrawal of blood. The resulting fatty acid curve in such instances not only failed to rise after the injection of adrenalin but at times fell, due, we believe, to the fact that the initial emotional response of the animal had already raised the fatty acid values to a high level. Only in a few well trained rabbits, in which pentobarbital was very carefully employed to quiet them, did we obtain curves similar to those reported in Table II.

That this response of the fatty acids can occur very rapidly is shown by the fact that frequently in human beings we have noted an almost maximal rise within fifteen minutes after the injection of adrenalin. If we regard the response as in a sense an emergency one, and comparable with the other well-known effects of adrenalin it is not unreasonable to expect it to reach its maximum in a relatively short period of time. From such considerations we believe our findings are not necessarily inconsistent with those obtained by previous investigators.

The physiological significance of the rise in blood fatty acids is not clear, but the suggestion obviously arises that it may be associated with the rapid mobilization of energy-producing material either for immediate consumption or for storage elsewhere ta replace material which has been rapidly utilized.

\section{OBSERVATIONS ON PATIENTS WITH HEPATIC DISEASE}

As already mentioned it has been known for some time that in many patients suffering from various forms of hepatic disorders the level of the plasma lipids is considerably elevated above normal. The exact mechanism underlying such an elevation of blood lipids is not understood. Because of this fact we determined to obtain a series of fatty acid curves in patients suffering from various diseases of the liver. It seemed that a comparison of the results obtained with those already noted in normal individuals might provide further information regarding the mechanism involved in the normal rise in fatty acids 
following the intramuscular injection of adrenalin and might also provide a means of studying disturbances of hepatic function. The results of these studies are given below.

\section{Clinical material}

The clinical material subjected to investigation included various types of liver disease and was selected from ward and private patients. In the 43 patients studied, the ultimate outcome is known in every case and in many instances the individual patients have been followed closely for more than three years. In general, it may be stated that the patients were suffering from acute infectious or toxic hepatic disorders, such as catarrhal jaundice or cinchophen poisoning, or from chronic disturbances, such as are encountered in the various forms of cirrhosis. The diagnosis was usually obvious, and in one-third of the cases was confirmed by operation or by necropsy.

\section{Methods of study}

A curve of fatty acid values was obtained following the intramuscular injection of adrenalin, as already described. The patients were at rest in bed throughout the full two-hour period. In most instances a quantitative determination of the plasma bilirubin was made by the method of van den Bergh and a bromsulphalein retention test was performed as a further means of studying hepatic dysfunction and for comparison with the results of the blood lipid studies.

\section{Results}

The curve obtained from a study of normal individuals has been shown in Figure 1. As already noted its configuration indicates a consistent tendency in normal individuals to a definite rise in blood fatty acids after the intramuscular injection of adrenalin, with a subsequent return to the fasting level. Because of the known high fasting values for plasma lipids in hepatic disorders it seemed wise to determine, if possible, whether the existence of a high fasting level of blood fatty acids would affect the character of the response to adrenalin. Observations were made on three patients with chronic nephritis with high fasting values of blood fatty acids. The results are shown in Figure 2 and may be com-

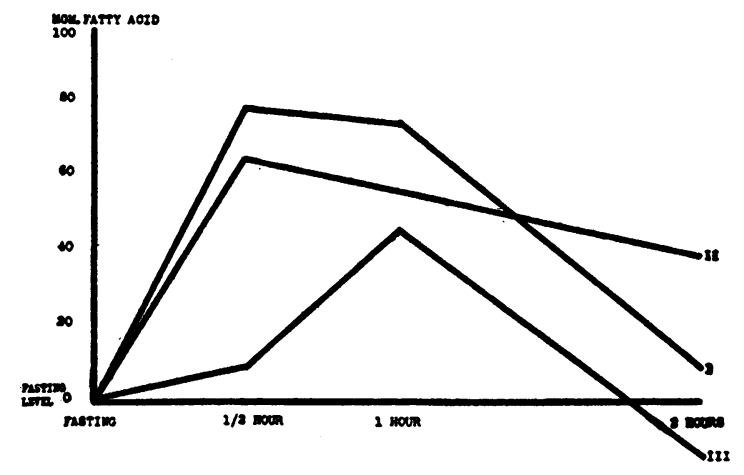

Fig. 2. Fatty Acid Curves Obtained in Patients With Chronic Nephritis.

The fasting level differs in each instance but for comparison graphs are drawn with $\mathrm{O}$ as the fasting level.

Fasting level values: $\mathrm{I}-\mathrm{Nephrosis}=607 \mathrm{mgm}$.

II-Nephrosis $=511 \mathrm{mgm}$.

III-Uremia, chronic glomerular nephritis $=363 \mathrm{mgm}$.

pared with the so-called normal curve in Figure 1. The fasting values were 607,511 , and 363 mgm. respectively. In the case represented by Curve III, Figure 2, starvation, a known cause of an increased value for plasma lipids, was added to the known existence of a nephritis. It will be noted that in each instance the curves obtained showed a marked rise to a peak after the injection of adrenalin and a subsequent fall approximately to the previous fasting level.

The curves presented in Figure 3 were obtained from two patients who were recovering from acute toxic liver injury. In both instances the "control" curve was obtained while the patients were on a low fat diet. The curves obtained after the administration of a high fat diet for a period of three days are given for comparison. Although the fasting level of the blood fatty acids was appreciably higher after the change in diet there still was noted a sharp rise in the blood lipids following the administration of adrenalin.

From the above observations, it would seem that an abnormally high fasting level of the blood fatty acids when due to a high fat intake, or to conditions such as exist in starvation or in nephritis, does not prevent a rise in fatty acids following the intramuscular administration of adrenalin, with a subsequent fall to the fasting level. Even under such conditions this response to adrenalin resembled that obtained in normal individuals. 

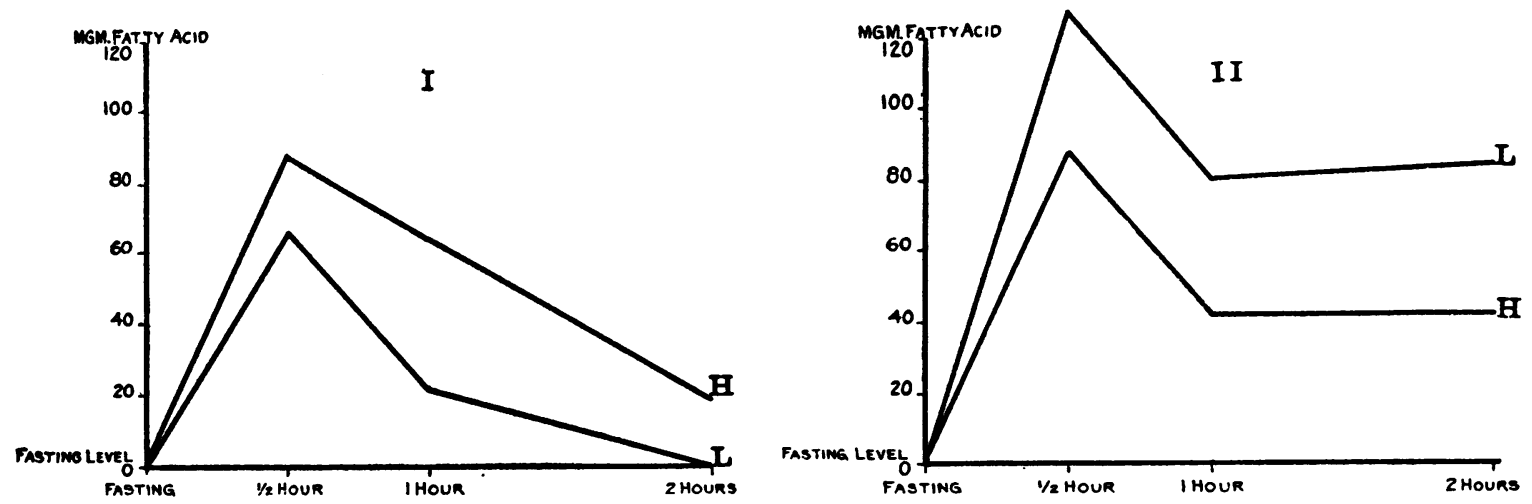

Fig. 3. Fatty Acid Curves Obtained on Two Patients with Toxic Jaundice (I) Antimony Poisoning:

(II) Arsphenamine Poisoning

Curves marked $\mathrm{H}$ obtained during the feeding on high fat diet. Curves marked $\mathrm{L}$ obtained during feeding on low fat diet. As in previous charts the fasting levels are charted at identical points although they actually represent different values as given above.

I. Fasting level high fat diet $=563 \mathrm{mgm}$.

Fasting level low fat diet $=550 \mathrm{mgm}$.

II. Fasting level high fat diet $=551 \mathrm{mgm}$.

Fasting level low fat diet $=466 \mathrm{mgm}$.
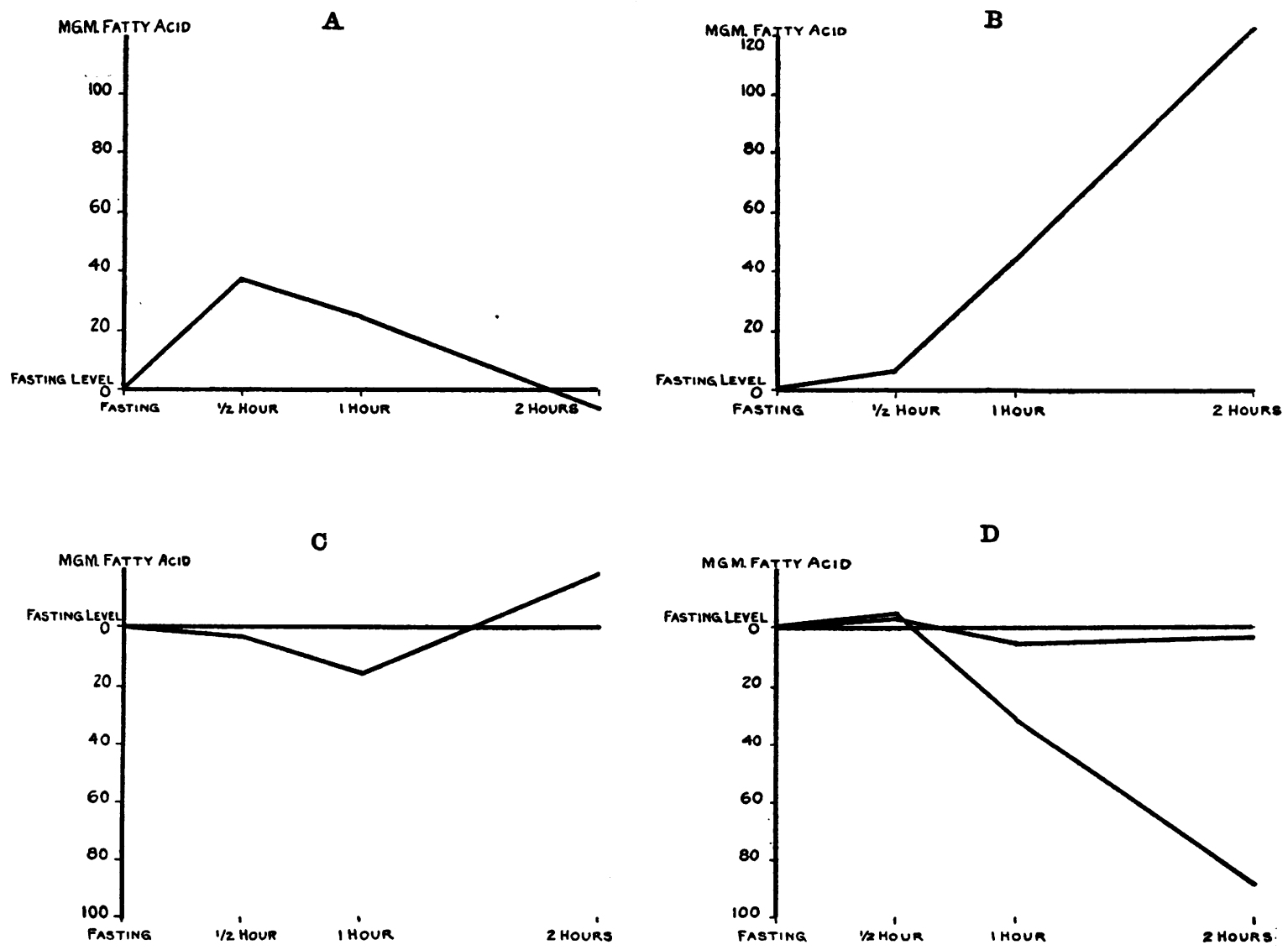

Fig. 4. Types A, B, C, and D of Fatty Acid Curves as Obtained After Intramuscular Injection of Adrenalin in Normal Patients and in Patients with Liver Disease. (See text.)

Two D Curves are given, one showing no appreciable change from fasting level and the other showing the continuous fall. 
It seems reasonable to assume, therefore, that the high fasting fatty acid values encountered in diseases of the liver would not in themselves alter the response to adrenalin.

We have divided the curves obtained from the group of 43 patients with various types of hepatic disease into three arbitrary types and have classified them for comparison with the normal as follows (see Figure 4):

"A" (normal) Curve-This curve is characterized by an appreciable rise which usually appeared within one-half hour after the administration of adrenalin, and a return to approximately a fasting level at the end of two hours.

" B" Curve-A curve showing no initial fall in fatty acids after the administration of adrenalin, but a rather continuous rise of at least $15 \mathrm{mgm}$. per $100 \mathrm{cc}$. within two hours, with little if any terminal drop.

" $C$ " Curve-A curve showing a fall in the fatty acids below the fasting level, followed by a rise to at least the fasting level.

" D" Curve-A curve showing no rise or fall of more than $5 \mathrm{mgm}$. from the fasting level, or a continuous fall.

\section{Results}

We have grouped our results in relation to such a classification of the various curves obtained. The findings are tabulated in Table III together

TABLE III

Data obtained from cases of hepatic disease following the intramuscular injection of 0.5 cc. adrenalin (1:1000 solution)

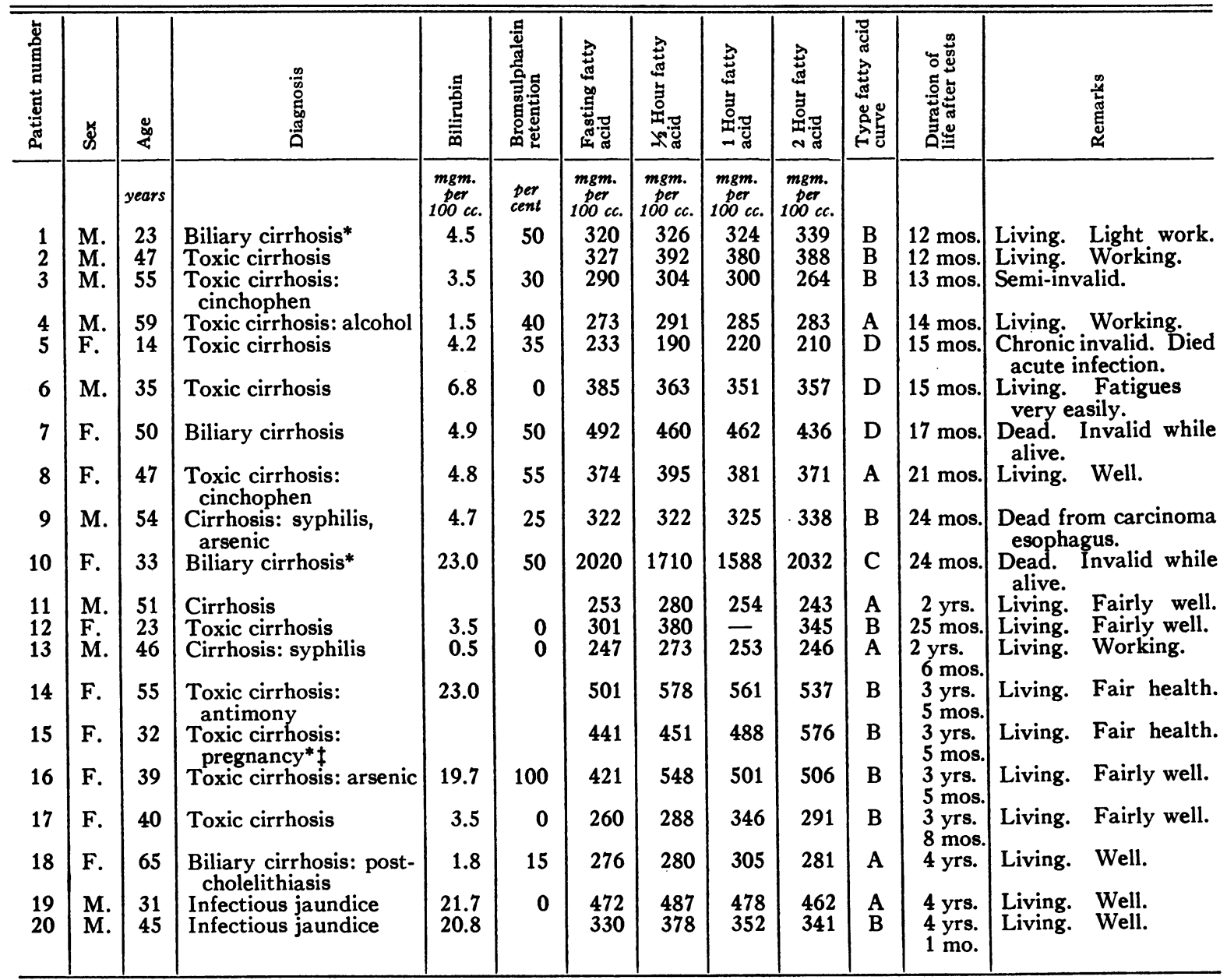

* Confirmed at operation.

$\dagger$ Confirmed at autopsy.

$\ddagger$ Five months pregnant. 
TABLE III-Continued

\begin{tabular}{|c|c|c|c|c|c|c|c|c|c|c|c|c|}
\hline 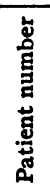 & \& & 产 & 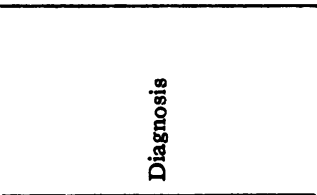 & 芦 & 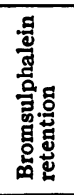 & 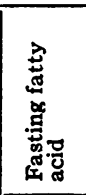 & 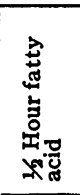 & 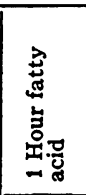 & 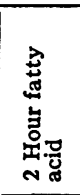 & 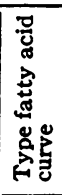 & 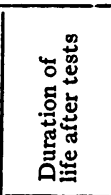 & 峦 \\
\hline & & years & & $\begin{array}{l}\text { mgm. } \\
\text { per } \\
100 \mathrm{cc} .\end{array}$ & $\begin{array}{l}\text { per } \\
\text { cent }\end{array}$ & $\begin{array}{l}\text { mgm. } \\
\text { per } \\
100 \mathrm{cc} .\end{array}$ & $\begin{array}{l}\text { mgm. } \\
\text { per } \\
100 \mathrm{cc} .\end{array}$ & $\begin{array}{c}\text { mgm. } \\
\text { per } \\
100 \text { cc. }\end{array}$ & $\begin{array}{l}\text { mgm. } \\
\text { per } \\
100 \mathrm{cc} .\end{array}$ & & & \\
\hline 21 & M. & 46 & Toxic cirrhosis: alcohol & 0.5 & 50 & 338 & 365 & 373 & 379 & B & $\begin{array}{l}4 \mathrm{yrs} \text {. } \\
4 \mathrm{mos} \text {. }\end{array}$ & $\begin{array}{l}\text { Dead. Well until } \\
\text { acute terminal }\end{array}$ \\
\hline 22 & F. & 23 & Infectious jaundice & 15.6 & 25 & 608 & 659 & 610 & 601 & $\mathbf{A}$ & 4 yrs. & Living. Well. \\
\hline 23 & F. & 37 & Toxic cirrhosis* & 0.5 & 20 & 547 & 504 & 435 & 446 & D & 4 yrs. & Living. Fatigues \\
\hline 24 & M. & 48 & $\begin{array}{l}\text { Acute yellow atrophy: } \\
\text { - Cause? }\end{array}$ & 15.0 & 100 & 271 & 271 & 249 & 252 & D & 1 day. & Dead \\
\hline 25 & M. & 45 & $\begin{array}{l}\text { Toxic cirrhosis: } \uparrow \\
\text { alcohol }\end{array}$ & 6.6 & 40 & 198 & 188 & 202 & 190 & C & 2 days & Dead \\
\hline 26 & M. & 35 & Toxic cirrhosis: alcohol & 1.5 & 25 & 286 & 292 & 272 & 269 & D & 5 days & Dead. Acute yellow \\
\hline 27 & M. & 66 & Cancer of pancreas* & 19.8 & & 380 & 376 & 398 & 383 & B & 10 days & Dead. Postoperative \\
\hline 28 & M. & 42 & $\begin{array}{l}\text { Acute yellow atrophy; } \\
\text { pylephlebitis? }\end{array}$ & 18.0 & 100 & 323 & 318 & 311 & 312 & D & 10 days & Dead. \\
\hline 29 & M. & 63 & $\begin{array}{l}\text { Carcinoma of pan- } \\
\text { creas }^{*} \dagger\end{array}$ & 16.3 & 100 & 453 & 444 & 420 & 415 & D & 12 days & $\begin{array}{l}\text { Dead. } 9 \text { days post- } \\
\text { operative. }\end{array}$ \\
\hline $\begin{array}{l}30 \\
31\end{array}$ & $\mathrm{~F}$. & $\begin{array}{l}48 \\
67\end{array}$ & $\begin{array}{l}\text { Carcinoma bile ducts } \dagger \\
\text { Toxic cirrhosis: } \dagger\end{array}$ & $\begin{array}{r}30.0 \\
4.8\end{array}$ & 70 & $\begin{array}{r}1336 \\
383\end{array}$ & $\begin{array}{r}1341 \\
362\end{array}$ & $\begin{array}{r}1298 \\
356\end{array}$ & $\begin{array}{r}1310 \\
351\end{array}$ & $\begin{array}{l}\mathrm{D} \\
\mathrm{D}\end{array}$ & $\begin{array}{l}16 \text { days } \\
3 \text { wks. }\end{array}$ & $\begin{array}{l}\text { Dead. Cholemia. } \\
\text { Dead. Che }\end{array}$ \\
\hline 32 & M. & 45 & $\begin{array}{l}\text { Pylephlebitis: post- } \\
\text { cholecystectomy }\end{array}$ & 2.0 & 25 & 364 & 355 & 317 & 302 & D & 3 wks. & Dead. Toxemia. \\
\hline $\begin{array}{l}33 \\
34 \\
35\end{array}$ & $\begin{array}{l}\mathrm{F} . \\
\mathrm{M} .\end{array}$ & $\begin{array}{l}50 \\
20 \\
48\end{array}$ & $\begin{array}{l}\text { Biliary cirrhosis } \dagger \\
\text { Biliary cirrhosis } \\
\text { Toxic cirrhosis }\end{array}$ & $\begin{array}{r}23.4 \\
6.0 \\
3.4\end{array}$ & $\begin{array}{r}100 \\
55 \\
60\end{array}$ & $\begin{array}{l}404 \\
242 \\
327\end{array}$ & $\begin{array}{l}396 \\
239 \\
368\end{array}$ & $\begin{array}{l}381 \\
227\end{array}$ & $\begin{array}{l}343 \\
260 \\
332\end{array}$ & $\begin{array}{l}\mathbf{D} \\
\mathbf{C} \\
\mathbf{A}\end{array}$ & $\begin{array}{l}1 \text { mo. } \\
6 \text { wks. } \\
3 \text { mos. }\end{array}$ & $\begin{array}{l}\text { Dead. } \\
\text { Dead. } \\
\text { Dead. Acute hemor- }\end{array}$ \\
\hline $\begin{array}{l}36 \\
37 \\
38 \\
39\end{array}$ & $\begin{array}{l}\mathrm{F} . \\
\mathrm{F} . \\
\mathrm{M} .\end{array}$ & $\begin{array}{l}38 \\
37 \\
49 \\
54\end{array}$ & $\begin{array}{l}\text { Biliary cirrhosis* } \\
\text { Toxic cirrhosis* } \\
\text { Toxic cirrhosis: alcohol } \\
\text { Toxic cirrhosis: alcohol }\end{array}$ & $\begin{array}{l}6.6 \\
2.5 \\
3.8 \\
2.0\end{array}$ & $\begin{array}{l}35 \\
35 \\
35 \\
70\end{array}$ & $\begin{array}{l}418 \\
270 \\
475 \\
242\end{array}$ & $\begin{array}{l}426 \\
262 \\
479 \\
213\end{array}$ & $\begin{array}{l}422 \\
277 \\
444 \\
204\end{array}$ & $\begin{array}{l}422 \\
274 \\
387 \\
159\end{array}$ & $\begin{array}{l}\mathrm{D} \\
\mathrm{C} \\
\mathrm{D} \\
\mathrm{D}\end{array}$ & $\begin{array}{l}3 \mathrm{mos} . \\
3 \mathrm{mos} . \\
3 \mathrm{mos} . \\
6 \mathrm{mos} .\end{array}$ & $\begin{array}{l}\text { rnage. } \\
\text { Dead. Cholemia. } \\
\text { Dead. Cholemia. } \\
\text { Dead. Cholemia. } \\
\text { Dead. Acute yellow }\end{array}$ \\
\hline $\begin{array}{l}40 \\
41 \\
42\end{array}$ & $\begin{array}{l}\text { M. } \\
\text { M. } \\
\text { M. }\end{array}$ & $\begin{array}{l}26 \\
30 \\
62\end{array}$ & $\begin{array}{l}\text { Syphilis } \\
\text { Biliary cirrhosis* } \\
\text { Biliary cirrhosis* }\end{array}$ & $\begin{array}{l}22.5 \\
15.5 \\
24.0\end{array}$ & $\begin{array}{r}100 \\
35 \\
100\end{array}$ & $\begin{array}{l}679 \\
619 \\
489\end{array}$ & $\begin{array}{l}604 \\
608 \\
492\end{array}$ & $\begin{array}{l}602 \\
636 \\
484\end{array}$ & $\begin{array}{l}568 \\
681 \\
486\end{array}$ & $\begin{array}{l}\mathrm{D} \\
\mathrm{C} \\
\mathbf{D}\end{array}$ & $\begin{array}{l}7 \mathrm{mos} \\
7 \mathrm{mos} . \\
7 \mathrm{mos} .\end{array}$ & $\begin{array}{l}\text { atropny. } \\
\text { Dead. Cholemia. } \\
\text { Dead. Chollow } \\
\text { Dead. Acute yellow }\end{array}$ \\
\hline 43 & F. & 32 & Toxic cirrhosis $\dagger$ & 5.6 & 65 & 266 & 255 & 274 & 290 & $\mathrm{C}$ & $8 \mathrm{mos}$. & $\begin{array}{l}\text { Dead. Pneumonia } \\
\text { after exploration. }\end{array}$ \\
\hline
\end{tabular}

with certain other laboratory and clinical data. In each instance we have given the actual values obtained for the variations in blood fatty acid, and have also classified the curve according to the above arbitrary standards.

\section{Discussion}

These findings suggest that the character of the fatty acid curve obtained after the intramuscular injection of adrenalin in man tends to be definitely altered in conditions characterized by liver damage. The course of the curve, as has been noted, seems to be independent of the initial level of the fatty acids. Of interest, clinically, is the possibility of prognostic value attaching to such curves in the presence of liver disturbances. Of the 43 patients studied 18 are living, with a survival period of from 8 to 52 months after the test was made. Of this group of 18 living individuals, 16 had either $A$ or $B$ curves. Of the 25 patients who died 21 had either $C$ or D curves. (See Table IV.)

Of the 20 patients with $\mathrm{A}$ or $\mathrm{B}$ curves all but two survived for more than a year after the observations were made. The average survival period was 30 months with 5 patients living for more than 4 years. One of the group, Patient 27, lived only ten days after his blood was studied. He died of bronchopneumonia four days after a cholecystogastrostomy for carcinoma of the head 
TABLE IV

Tabulation of fatty acid curves in relation to survival and state of health

\begin{tabular}{|c|c|c|c|}
\hline $\begin{array}{l}\text { Type of } \\
\text { curve }\end{array}$ & $\begin{array}{l}\text { Number of } \\
\text { cases well }\end{array}$ & $\begin{array}{l}\text { Number of } \\
\text { cases invalid }\end{array}$ & $\begin{array}{l}\text { Number of } \\
\text { cases dead }\end{array}$ \\
\hline $\begin{array}{l}\mathbf{A} \ldots \ldots \ldots \ldots \\
\mathbf{B} \ldots \ldots \cdots \cdots \\
\mathbf{C} \ldots \ldots \ldots \ldots\end{array}$ & $\begin{array}{l}6 \\
2 \\
0 \\
0\end{array}$ & $\begin{array}{l}1 \\
7 \\
0 \\
2\end{array}$ & $\begin{array}{l}1 \\
3^{*} \\
6 \\
15\end{array}$ \\
\hline
\end{tabular}

* Cancer esophagus, cellulitis of leg, and postoperative death, respectively.

of the pancreas. The other case, Patient 35, died from a ruptured esophageal varix two months after the fatty acid determinations. Of these two deaths, one at least could hardly be attributed to hepatic insufficiency.

Two cases, Patients 9 and 21, with A or B curves died 29 and 52 months after the test was performed. During the entire survival period there were no symptoms referable to the underlying disease of the liver, and death occurred as a result of cancer of the esophagus and cellulitis of the leg respectively.

Of the 23 patients presenting $C$ or $D$ curves 18 died within 8 months of the observations following the injection of adrenalin. The average survival period of the group was 7 months, with 9 patients dying within a month of the test. Of the 5 patients with $C$ or $D$ curves who survived more than eight months, three died after 15 months, 17 months and 24 months respectively. Their course was one of almost continuous invalidism.

A comparison of the relation existing between the type of curves obtained and the degree of liver damage as measured by standard liver function tests or by clinical findings made at the time of the fatty acid determinations is made in Tables $\mathrm{V}$ and VI.

TABLE V

Comparison between (1) type of curve obtained, (2) serum bilirubin, and (3) bromsulphalein retention

\begin{tabular}{|c|c|c|c|}
\hline $\begin{array}{l}\text { Type } \\
\text { of } \\
\text { curve }\end{array}$ & $\begin{array}{c}\text { Number } \\
\text { of } \\
\text { cases }\end{array}$ & $\begin{array}{c}\text { Mean serum } \\
\text { bilirubin }\end{array}$ & $\begin{array}{c}\text { Mean } \\
\text { bromsulphalein } \\
\text { retention }\end{array}$ \\
\hline $\begin{array}{l}A \ldots \ldots \\
\mathbf{B} \ldots \ldots \\
\mathrm{C} \ldots \ldots \\
\mathrm{D} \ldots \ldots\end{array}$ & $\begin{array}{r}7 \\
7 \\
6 \\
16\end{array}$ & $\begin{array}{c}\text { mgm. per } 100 \mathrm{cc} \text {. } \\
7.0 \\
9.0 \\
9.8 \\
10.9\end{array}$ & $\begin{array}{c}\text { per cent } \\
28.0 \\
36.4 \\
46.5 \\
59.4\end{array}$ \\
\hline
\end{tabular}

TABLE VI

Comparison between the type of curve obtained and the presence of edema and ascites

\begin{tabular}{c|c|c|c}
\hline $\begin{array}{c}\text { Type } \\
\text { of } \\
\text { curve }\end{array}$ & $\begin{array}{c}\text { Number } \\
\text { of } \\
\text { cases }\end{array}$ & $\begin{array}{c}\text { Number of } \\
\text { cases showing } \\
\text { ascites }\end{array}$ & $\begin{array}{c}\text { Number of } \\
\text { cases showing } \\
\text { edema }\end{array}$ \\
\hline A and B.... & 20 & 6 & 6 \\
C and D... & 23 & 13 & 11 \\
\hline
\end{tabular}

It seems obvious, from these findings, that not only do those patients with A and B curves have a much longer survival period than those with $C$ and $\mathrm{D}$ curves, but in addition such curves are associated with less marked evidence of serious liver damage as measured by the usual clinical and laboratory methods.

Although the variations observed in the fatty acid curves correspond in general to the apparent severity of the hepatic disturbance as measured by the presence of edema or ascites, or by the intensity of the jaundice and the degree of dye retention, this is not true in every individual case. In several patients the severity of the liver damage, as indicated by the other laboratory tests or by clinical findings failed to be reflected in the type of fatty acid curve. In such instances the subsequent course proved that the fatty acid curve was the best guide to prognosis. The findings in Patient 8 illustrate this. In this case the patient had been jaundiced for two months after prolonged administration of cinchophen. On admission she showed moderate jaundice, emaciation, purpura, ascites, marked edema, and bilateral pleural effusion. The liver and spleen were both enlarged, and the clinical picture was that of a very severe liver toxemia, probably with subacute yellow atrophy. The bilirubin was $4.8 \mathrm{mgm}$. per 100 cc., the bromsulphalein retention was 55 per cent at the end of 30 minutes, and the red blood count was only $3,900,000$ cells per cu. $\mathrm{mm}$. The urine was heavily bile stained and the stools were clay colored. In spite of such obvious severe liver damage the fatty acid curve was normal in shape. Under proper treatment recovery was unusually prompt, and the patient is now working full time 30 months after the test was performed. The prognosis given by several observers was unfavorable, but actually the patient did extremely well.

An example of the opposite situation is also of interest. Patient 32, ten days after a chole- 
cystectomy began to run a slightly elevated temperature, and became very slightly jaundiced. Physical signs, with the exception of the slight jaundice revealed nothing. The serum bilirubin was $1.9 \mathrm{mgm}$. per $100 \mathrm{cc}$. and the bromsulphalein retention was 35 per cent. Ten days later the clinical condition of the patient apparently was unchanged but the bromsulphalein retention had dropped to 20 per cent, suggesting definite improvement. A fatty acid curve done at this time showed a typical D curve. In spite of the apparent improvement, as indicated by the better dye excretion, the patient became progressively worse from this point in the disease, and died in three weeks. Autopsy showed multiple small areas of infection and necrosis throughout the liver.

From such findings it would appear that a correct interpretation of the fatty acid curve offers a valuable method for prognosis, as compared with other laboratory tests or clinical findings. Examination of our results reveals the fact that in only one instance, Patient 35, was an A curve associated with a short survival period. Moreover, in this instance death occurred from an acute hemorrhage, presumably from esophageal varices, rather than from liver insufficiency. Only two patients with $\mathrm{D}$ curves failed to do poorly. One, Patient 6 , is a semi-invalid, and has been limited in his activity much of the time during his fifteen months survival. The other, $\mathrm{Pa}$ tient 23 , still survives after more than four years, and while now a semi-invalid, would seem to be a distinct exception to our prognostic rule.

It seems to us that a determination of the blood fatty acid curve after the intramuscular injection of adrenalin offers prognostic aid in patients with liver disease, and apparently regardless of the type of hepatic involvement. As with every other laboratory test there are exceptions to the rule, but we believe these will be few in number, and will not seriously reduce the value of the test. We suggest that the test may be of particular importance as an aid to prognosis in those acute or subacute conditions involving the liver in which other observations seem to indicate very serious involvement of the organ, and it is of particular interest that apparently important deductions may be suggested by a single test. In this respect it would seem to have an advantage over other lab- oratory procedures where repeated observations seem to be necessary in order to obtain information of prognostic importance. From our findings we are inclined to believe that according to our arbitrary classification $\mathrm{A}$ and $\mathrm{B}$ curves indicate a relatively excellent prognosis even in the face of apparently severe liver injury provided adequate treatment is instituted; C and D curves suggest a prognosis of chronic invalidism or of a relatively short survival period.

The blood sugar findings corresponding to the fatty acid curves are not given in detail, but corresponded to those reported by Loeb, Reeves and Glasier (15). They seemed to show no constant changes consistent with the underlying hepatic condition.

\section{SUM MARY}

1. We have studied the effect of the intramuscular injection of adrenalin upon the blood fatty acids in thirteen normal human beings.

2. Our observations show an almost constant type of response which consists in a fairly sharp but moderate rise in the plasma fatty acids within about one-half hour after the injection of the drug followed by a subsequent return nearly to the fasting level in about two hours.

3. We have presented evidence that in patients suffering from disorders of the liver there is an abnormal response of the blood fatty acids to the intramuscular injection of adrenalin.

4. We suggest that this abnormal response of the blood fatty acids may be used as a valuable guide to prognosis in patients with liver disease.

\section{BIBLIOGRAPHY}

1. Himwich, H. E., and Petermann, M. L., Effect of adrenalin on blood fat. Proc. Soc. Exper. Biol. and Med., 1930, 27, 814.

2. Himwich, H. E., and Fulton, J. F., The effect of emotional stress on blood fat. Am. J. Physiol. (Proc.), 1931, 97, 533.

3. Himwich, H. E., and Spiers, M. A., Effects of adrenalin, ephedrine, and insulin on blood fat. Am. J. Physiol., 1931, 97, 648.

4. Koskoff, Y. D., and Dusser de Barenne, J. G., On reflex hyperlipaemia. Science, 1931, 74, 550.

5. Rony, H. R., and Ching, T. T., Studies on fat metabolism. II. The effects of certain hormones on fat transport. Endocrinology, 1930, 14, 355. 
6. Bornstein, A., and Müller, E., Über den respiratorischen Stoffwechsel bei toxischen Glykämien. Biochem. Ztschr., 1921, 126, 64.

7. Alpern, D., and Collazzo, J. A., Uber den Einfluss des Adrenalins auf den Blutchemismus in der Norm, im Hungerzustande und bei der Avitaminose. Ztschr. f. d. ges. exper. Med., 1923, 35, 288.

8. Raab, W., Das hormonal-nervöse Regulations system des Fettstoff wechsels. Ztschr. f. d. ges. exper. Med., 1926, 49, 179.

9. Alpern, D., and Tutkewitsch, L., Vegetativ-endokrines System als Regulator des intermediären Stoffwechsels. I. Die Rolle des Adrenalins bei der Regulation der Kohlehydrat und Fettbestandteile des Blutes. Biochem. Ztschr., 1929, 215, 319.
10. Long, C. N. H., and Venning, E. M., The alleged increase in plasma fats after the injection of epinephrine. J. Biol. Chem., 1932, 96, 397.

11. Stewart, C. P., and White, A. C., The estimation of fat in blood. Biochem. J., 1925, 19, 840.

12. Himwich, H. E., Friedman, H., and Spiers, M. A., A modification of the method of Stewart and White for determination of blood-fat, with observations on several species. in post-absorptive conditions. Biochem. J., 1931, 25, 1839.

13. Stoddard, J. L., and Drury, P. E., A titration method for blood fat. J. Biol. Chem., 1929, 84, 741.

14. Unpublished data.

15. Loeb, R. F., Reeves, E. B., and Glasier, H. P., Responses to the injection of epinephrine in hepatic disease. J. Clin. Invest., 1931, 10, 19. 